\title{
PEMBELAJARAN KALKULUS BERBASIS 4K UNTUK MENINGKATKAN KEMAMPUAN PEMECAHAN MASALAH MATEMATIKA
}

\author{
Siti Napfiah ${ }^{1}$, Yunis Sulistyorini ${ }^{2}$ \\ ${ }^{1}$ IKIP Budi Utomo Malang \\ napfiahsiti@gmail.com \\ ${ }^{2}$ IKIP Budi Utomo Malang \\ yunis.sulistyorini@gmail.com
}

\begin{abstract}
ABSTRAK
Artikel ini mendeskripsikan penerapan pembelajaran Kalkulus berbasis 4K (Kritis, Kreatif, Komunikatif, dan Kolaboratif) untuk meningkatkan kemampuan mahasiswa dalam memecahkan masalah matematika. Penelitian ini merupakan penelitian tindakan kelas. Subjek penelitian ini adalah mahasiswa program studi Pendidikan Matematika IKIP Budi Utomo Malang. Langkah-langkah pembelajaran berbasis $4 \mathrm{~K}$ yang dapat meningkatkan kemampuan pemecahan masalah yaitu mahasiswa diberikan permasalahan yang mendorong untuk berpikir kritis dan kreatif; mereka diminta untuk berkolaborasi dan berkomunikasi dalam kelompok; dilakukan kegiatan demonstrasi yang menuntut setiap mahasiswa berkomunikasi di hadapan teman sekelas; dan mahasiswa diminta membuat permasalahan yang mendorong untuk berpikir kreatif. Skor rata-rata kemampuan mahasiswa dalam memecahkan masalah meningkat dari 22.5 pada studi pendahuluan menjadi 60 pada siklus I dan 79.75 pada siklus II. Dengan demikian pembelajaran 4K dapat meningkatkan kemampuan pemecahan masalah mahasiswa.
\end{abstract}

Kata Kunci: kalkulus, 4K, pemecahan masalah

\begin{abstract}
This article describes the application of 4C (Critical, Creative, Communicative, and Collaborative) in Calculus learning to improve students' ability to solve mathematical problems. This research was classroom action research. Subjects of this study were students of IKIP Budi Utomo Malang Mathematics Education program. Steps of 4C learning that can improve problem solving skills were (1) students were given problems that encourage critical and creative thinking, (2) they were asked to collaborate and communicate in groups, (3) demonstration activities that require each student to communicate in front of classmates, (4) students asked to make problems that encourage creative thinking. The results of the study indicate that there was an increase in student's ability to solve problems after being given 4C learning. In the preliminary study, most students were able to understand problem, but few students were able to make plan and implement plan. The average score of students' problem solving skill improved from 22.5 in the preliminary study to 60 in the first cycle and 79.75 in the second cycle. So 4C learning can improve students' problem solving skills.
\end{abstract}

Keywords: calculus, 4C, problem solving 
Format Sitasi: Napfiah, S., \& Sulistyorini, Y. (2019). Pembelajaran Kalkulus Berbasis 4K untuk Meningkatkan Kemampuan Pemecahan Masalah Matematika. Kalamatika: Jurnal Pendidikan Matematika, 4(2), 193-204.

Penyerahan Naskah: 30 July 2019 || Revisi: 26 November 2019 || Diterima: 28 November 2019

\section{PENDAHULUAN}

Pemecahan masalah merupakan salah satu kemampuan yang harus dikuasai mahasiswa. Pemecahan masalah merupakan salah satu standar proses yang harus dikuasai dalam pembelajaran matematika (NCTM, 2000). Pemecahan masalah itu sendiri merupakan suatu aktivitas intelektual untuk mencari penyelesaian masalah yang dihadapi dengan menggunakan bekal pengetahuan yang sudah dimiliki (Yarmayani, 2016). Sedangkan pembelajaran pemecahan masalah adalah suatu tindakan yang dilakukan guru agar siswanya termotivasi untuk menerima tantangan yang ada pada pertanyaan (soal) dan mengarahkan siswa dalam proses pemecahannya (Shadiq, 2004).

Pemecahan masalah sangat berhubungan dengan pembelajaran matematika. Pemecahan masalah merupakan bagian yang tidak terpisahkan dalam matematika (Ersoy, 2016) . Selain itu, kemampuan pemecahan masalah merupakan bagian dari kurikulum matematika yang sangat penting atau dapat dikatakan bahwa kemampuan memecahkan masalah merupakan hasil utama dari suatu proses pembelajaran (Yarmayani, 2016). Bahkan, pemecahan masalah itu sendiri bukan hanya dianggap sebagai tujuan pembelajaran matematika namun juga alat utama untuk bekerja dalam matematika (Eviyanti, dkk, 2017).

Pemecahan masalah terdiri dari beberapa tahapan. Polya dalam Ersoy (2016) menyatakan empat tahapan dalam memecahkan masalah yaitu memahami masalah, membuat rencana, melaksanakan rencana dan memeriksa kembali. Dalam memecahkan masalah tersebut diperlukan kreativitas, pengetahuan serta aplikasinya dalam kehidupan sehari-hari (Yarmayani, 2016) dan juga kemampuan bernalar dan komunikasi, serta sikap yang baik terhadap matematika (Ninik, Hobri, \& Suharto, 2014). Pemberian tugas atau masalah terbuka dapat dilakukan untuk memfokuskan pembelajaran pada pemecahan masalah sekaligus meningkatkan komunikasi di kelas (Pehkonen, Naveri, \& Laine, 2013).

Pemecahan masalah ini mempunyai beberapa kelebihan. Manfaat yang dapat diperoleh dari pemecahan masalah yaitu (1) siswa akan belajar bahwa ada banyak cara untuk menyelesaikan suatu soal (berpikir divergen) dan ada lebih dari satu solusi yang mungkin dari 
suatu soal, (2) siswa terlatih untuk melakukan eksplorasi, berpikir komprehensif, dan bernalar secara logis, dan (3) mengembangkan kemampuan komunikasi, dan membentuk nilai-nilai social melalui kerja kelompok (Yarmayani, 2016). Selain itu, keterampilan serta kemampuan berpikir yang didapat ketika seseorang memecahkan masalah akan dapat digunakan ketika menghadapai masalah di dalam kehidupan sehari-hari (Shadiq, 2004). Memfokuskan pembelajaran pada pemecahan masalah juga dapat mengarahkan pada pengembangan kemampuan berpikir tingkat tinggi (Ersoy, 2016).

Pemecahan masalah faktanya merupakan bagian penting dalam pembelajaran matematika. Namun masih banyak mahasiswa yang belum menguasai kemampuan ini. Hal ini juga ditunjukkan pada mahasiswa program studi Pendidikan Matematika IKIP Budi Utomo Malang. Berdasarkan hasil observasi diketahui bahwa mahasiswa masih kesulitan jika diberikan soal yang non rutin. Padahal soal non rutin merupakan salah satu indikasi soal merupakan masalah yang harus dipecahkan (Shadiq, 2004). Selain itu, mahasiswa juga belum terbiasa untuk bernalar dan berkomunikasi yang sejatinya dapat dibiasakan melalui pemecahan masalah. Mengingat bahwa matematika bukan hanya tentang perhitungan namun juga mengajarkan bagaimana mengembangkan pemahaman dan kemampuan berpikir secara matematis (Pehkonen, Naveri \& Laine, 2013), berargumentasi dan bernegoisasi serta memecahkan suatu masalah baik dalam pelajaran matematika maupun dalam kehidupan sehari-hari (Masrurotullaily, Hobri, \& Suharto, 2013).

Fakta bahwa kemampuan pemecahan masalah mahasiswa masih rendah secara khusus ditunjukkan pada matakuliah Kalkulus. Padahal kalkulus merupakan salah satu matakuliah yang wajib dikuasai mahasiswa calon guru. Mengingat pentingnya kemampuan pemecahan masalah dalam pembelajaran matematika maka perhatian khusus perlu diberikan untuk menyelesaikan masalah ini. Salah satu alternatif yang dapat dipertimbangkan untuk meningkatkan kemampuan pemecahan masalah mahasiswa adalah menerapkan pembelajaran berbasis 4K. 4K terdiri dari kemampuan berpikir kritis, kreatif, komunikasi dan kolaborasi.

Kemampuan pertama, berpikir kritis ini merupakan kemampuan yang dapat dipelajari dan dilatihkan yang dengan kemampuan ini seseorang akan mampu memecahkan masalah secara efektif (Peter, 2012). Belajar untuk berpikir kritis mengarahkan siswa untuk mengembangkan kemampuan lain, seperti tingkat konsentrasi yang lebih baik, kemampuan analisis yang lebih dalam dan peningkatan proses berpikir menjadi lebih baik (Van Roekel, 
2014). Kemampuan kedua, berpikir kreatif dapat diwujudkan dengan menciptakan ide baru, memperluas ide atau konsep dasar untuk meningkatkan dan memaksimalkan upaya kreatif, dan mengaplikasikan ide kreatif sebagai kontribusi nyata dalam kehidupan (Yuniar, Sunardi \& Kurniawati, 2017) yang sangat dibutuhkan dalam memecahkan masalah (Yarmayani, 2016). Kemampuan ketiga, komunikasi digunakan untuk menyatakan gagasan matematis secara lisan, tulisan, serta menggambarkan secara visual, menginterpretasikan dan mengevaluasi gagasangagasan matematika secara lisan maupun tertulis, dan menggunakan istilah-istilah, simbolsimbol, dan struktur-struktur untuk memodelkan situasi atau permasalahan matematika (NCTM, 2000). Sedangkan kemampuan keempat, kolaborasi berarti bekerjasama dengan orang lain untuk mencapai tujuan yang sama (Victor, 2015).

Selain itu, 4K merupakan salah satu komponen penting dalam menghadapai tantangan di era globalisasi. Untuk dapat berpartisipasi penuh dalam masyarakat dengan menunjukkan performa yang baik dalam kehidupan pribadi, publik, maupun pekerjaan diperlukan pemahaman matematika yang baik (Mahajan, 2014). Sebagai persiapan untuk menghadapi masyarakat global, membelajarkan matematika dan materi pokok lainnya harus ditingkatkan dengan melibatkan kemampuan berpikir kritis, kreatif, komunikasi dan kolaborasi (Van Roekel, 2014). Dengan kata lain, dengan penerapan pembelajaran berbasis 4K ini bertujuan untuk meningkatkan kemampuan pemecahan masalah sekaligus membentuk mahasiswa menjadi pemikir kritis, kreator, komunikator dan kolabolator yang handal untuk berkompetisi di masyarakat global saat ini.

Penelitian dari Sulistyorini \& Napfiah (2019) menunjukkan bahwa berpikir kritis merupakan kemampuan yang dapat dipelajari dan dilatihkan agar mampu memecahkan masalah secara efektif. Maharani (2014) menyatakan bahwa kemampuan berpikir kreatif berpengaruh terhadap kemampuan seseorang dalam memecahkan masalah sehari-hari. Mahmudi (2009) menyatakan bahwa komunikasi tertulis dapat menggambarkan kemampuan siswa dalam mengorganisasi berbagai konsep untuk menyelesaikan masalah, sedangkan komunikasi lisan dapat berupa pengungkapan dan penjelasan verbal suatu gagasan matematika. Selanjutnya, Zubaidah (2010) menyatakan bahwa pembelajaran kolaboratif salah satunya menekankan pada pengembangan kemampuan pemecahan masalah. Penelitianpenelitian sebelumnya tersebut menunjukkan bahwa masing-masing komponen $4 \mathrm{~K}$ mempunyai hubungan dengan kemampuan pemecahan masalah. Namun dari penelitian- 
penelitian tersebut belum menunjukkan bagaimana peningkatan kemampuan pemecahan masalah melalui pembelajaran yang menekankan pada aspek $4 \mathrm{~K}$.

\section{METODE PENELITIAN}

Subjek penelitian ini yaitu mahasiswa program studi Pendidikan Matematika IKIP Budi Utomo Malang yang sedang menempuh mata kuliah Kalkulus. Penelitian ini merupakan penelitian tindakan kelas. Tindakan yang dilakukan pada penelitian ini meliputi perencanaan, pelaksanaan tindakan, pengamatan, dan refleksi. Pada tahap perencanaan, dilakukan penyusunan bahan ajar yang meliputi RPS, RPP, LKM, dan soal pemecahan masalah. Selain itu disusun pula beberapa instrumen penelitian yang dibutuhkan dalam pengambilan data seperti lembar pengamatan dan catatan lapangan. Bahan ajar yang dibuat yakni bahan ajar untuk mata kuliah Kalkulus berbasis 4K. Selanjutnya tahap pelaksanaan tindakan yakni melaksanankan pembelajaran Kalkulus berbasis 4K sesuai dengan bahan ajar yang telah disusun. Pada saat pelaksanaan tindakan dilakukan pengamatan terhadap proses pembelajaran yang sedang berlangsung dengan menggunakan lembar pengamatan dan catatan lapangan.

Instrumen yang digunakan pada penelitian ini yaitu peneliti sendiri, lembar pengamatan, catatan lapangan, danlembar soal. Peneliti sebagai perencana, pelaksana, penganalisis data, dan pada akhirnya sebagai pelapor hasil penelitian. Peneliti yang membuat perencanaan dalam penyusunan bahan ajar. Peneliti sebagai pelaksana dalam kegiatan pembelajaran. Peneliti yang menganalisis data yang diperoleh. Serta peneliti sendiri yang melaporkan hasil penelitian. Lembar pengamatan digunakan untuk mengamati aktivitas mahasiswa terkait aktivitas komunikasi dan kolaborasi selama pembelajran. Catatan lapangan merupakan catatan yang ditulis oleh observer untuk melengkapi data yang tidak termuat dalam lembar pengamatan mengenai situasi kelas selama pelaksanaan pembelajaran. Lembar soal berisi soal-soal esai jenis pemecahan masalah yang harus dikerjakan mahasiswa secara tertulis yang nantinya digunakan untuk melihat kemampuan pemecahan masalah mahasiswa.

Cara menganalisis data yaitu dengan menentukan skor yang diperoleh pada tes berdasarkan rubrik penilaian dalam lembar penilaian. Kriteria keberhasilan dalam penelitian ini yaitu apabila skor rata-rata mahasiswa di kelas untuk tiap tahapan pemecahan masalah mencapai skor lebih dari 70. Tahapan pemecahan masalah yang digunakan berdasarkan tahapan Polya. Tahapan memecahkan masalah berdasarkan Polya yaitu sebagai berikut.

1. Memahami masalah 
Tahap pertama ini yaitu memahami soal. Mahasiswa perlu mengetahui apa yang diketahui, apa saja yang ada, hubungan yang terkait serta apa yang ditanyakan. Hal yang dapat dilakukan yaitu menuliskan secara ringkas apa yang diketahui dan apa yang ditanyakan.

\section{Membuat rencana}

Mahasiswa perlu mengidentifikasi strategi yang dibutuhkan untuk menyelesaikan masalah. Hal yang dapat dilakukan diantaranya menyederhanakan masalah, mengurutkan informasi yang ada, menebak, mengidentifikasi pola, mengidentifikasi sub tujuan, membuat analogi, membuat tabel, mensketsa diagram, menguji semua kemungkinan, bekerja terbalik, eksperimen, simulasi, dan mengembangkan suatu model.

\section{Melaksanakan rencana}

Melaksanakan tindakan sesuai dengan yang sudah direncanakan. Hal yang dilakukan diantaranya melaksanakan penghitungan sesuai strategi atau langkah yang sudah dipilih. Jika rencana yang sudah dipilih tidak dapat terlaksana dengan baik karena terkendala sesuatu, maka melaksanakan rencana yang lain.

4. Memeriksa kembali

Hal yang perlu diperhatikan ketika memeriksa kembali yakni mengecek kembali semua informasi penting yang telah teridentifikasi, mengecek semua penghitungan yang terlibat, mempertimbangkan apakah solusi yang telah terlaksana logis, melihat alternatif penyelesaian yang lain, membaca pertanyaan kembali, dan bertanya kepada diri sendiri apakah pertanyaan sudah benar-benar terjawab.

Tabel 1. Indikator 4K dalam Pemecahan Masalah

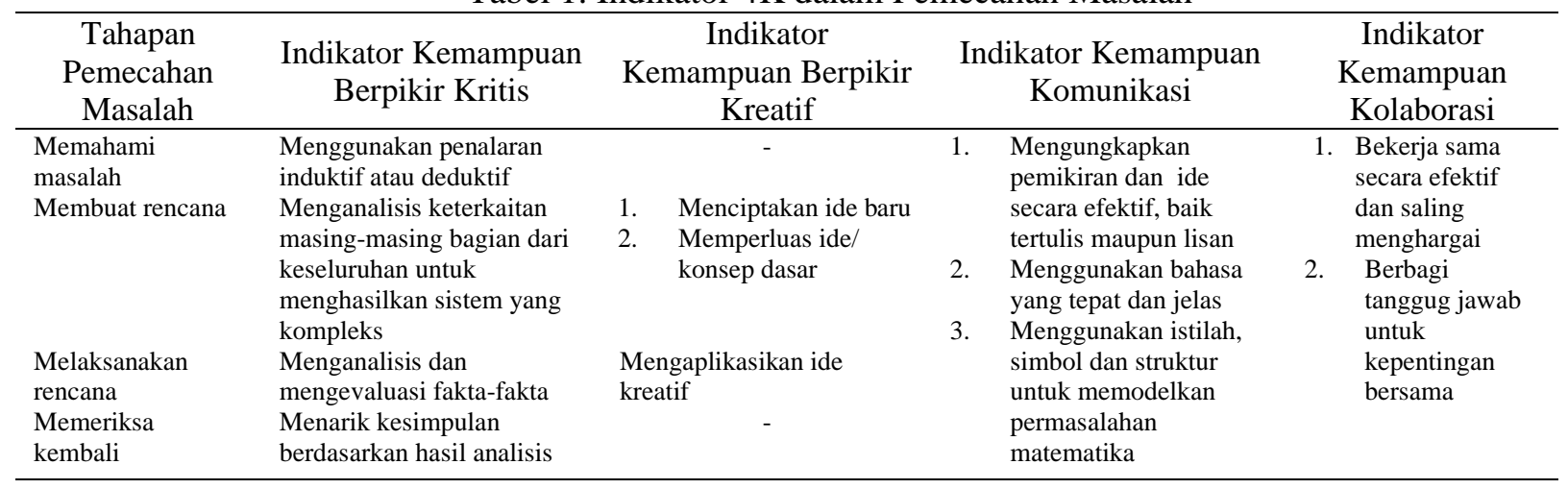




\section{HASIL DAN PEMBAHASAN}

Sebelum dilakukan tindakan penelitian, dilakukan studi pendahuluan. Studi pendahuluan dilaksanakan untuk mengetahui kemampuan awal mahasiswa dalam menyelesaikan soal jenis pemecahan masalah. Mahasiswa diberikan soal esai jenis pemecahan masalah dan diminta untuk menyelesaikannya. Pada studi pendahuluan ini diperoleh informasi bahwa skor rata-rata pemecahan masalah yang diperoleh untuk tiap tahapan pemecahan masalah yaitu untuk tahap memahami masalah diperoleh skor rata-rata 65, tahap membuat rencana diperoleh skor rata-rata 15, tahap melaksanankan rencana diperoleh skor rata-rata 10 , dan tahap memeriksa kembali diperoleh skor rata-rata 0 .

Selanjutnya dilaksanakanlah tindakan pembelajaran berbasis 4K. Langkah pembelajaran yang dilakukan yaitu mahasiswa diberikan LKM (Lembar Kerja Mahasiswa). Di dalam LKM ini terdapat berbagai soal matematika jenis pemecahan masalah. Masalah yang ditampilkan mendorong mahasiswa untuk berpikir kritis dan kreatif. Selanjutnya dilakukan pembelajaran kolaboratif serta memperhatikan komunikasi mahasiswa. Dosen memberikan arahan mengenai pembelajaran komunikatif dan kolaboratif yang bagus yakni diantaranya (1) mengungkapkan pemikiran dan ide secara efektif, baik tertulis maupun lisan, (2) berkomunikasi menggunakan bahasa yang tepat dan jelas, (3) menggunakan istilah, simbol dan struktur untuk memodelkan permasalahan matematika, (4) bekerja sama secara efektif dan saling menghargai, dan (5) berbagi tanggug jawab untuk kepentingan bersama. Setelah dilakasanakan pembelajaran Kalkulus berbasis 4K, mahasiswa diminta menyelesaiakan soal esai jenis pemecahan masalah. Serangkaian tindakan ini termasuk siklus I.

Berdasarkan hasil analisis data terhadap penelitian siklus I, diperoleh informasi bahwa untuk tahap memahami masalah diperoleh skor rata-rata 80, tahap membuat rencana diperoleh skor rata-rata 63, tahap melaksanankan rencana diperoleh skor rata-rata 52, dan untuk tahap memeriksa kembali diperoleh skor rata-rata 45. Berdasarkan informasi ini diketahui bahwa pembelajaran berbasis $4 \mathrm{~K}$ dapat meningkatkan kemampuan pemecahan masalah mahasiswa jika dibandingkan dengan pembelajaran yang tidak berbasis $4 \mathrm{~K}$ sesuai data yang diperoleh pada saat studi pendahuluan. Namun pada siklus I ini skor rata-rata mahasiswa untuk tiap tahapan belum mencapai skor lebih dari 70. Sehingga perlu dilakukan siklus II. Sebelum dilaksanakn tindakan siklus II pelu dilakukan refleksi terlebih dahulu. 
Refleksi dilakukan berdasarkan lembar pengamatan dan catatan lapangan dari observer. Pada kegiatan refleksi ditemukan kelemahan pada siklus I yakni beberapa mahasiswa menggantungkan kepada teman satu tim kelompoknya saat proses pembelajaran di kelas sehingga kurang maksimal dalam usaha mencoba menyelesaikan soal pemecahan masalah. Tindakan untuk memperbaiki siklus I yakni akan diusahakan setiap diri mahasiswa mempunyai tanggung jawab penuh dalam belajar untuk menyelesaikan masalah.

Tindakan yang dilakukan pada siklus II untuk memperbaiki siklus I yaitu setiap mahasiswa diminta untuk menjelaskan mengenai cara menyelesaikan permasalahan yang diajukan oleh dosen. Perbedaan pembelajaran pada siklus I dan siklus II yakni pada siklus I mahasiswa diminta menjelaskan materi secara berkelompok tanpa memperhatikan apakah yang menjelaskan semua anggota atau hanya perwakilan kelompok, sedangkan pada siklus II setiap anggota kelompok dituntut untuk menjelaskan di hadapan teman sekelas. Setelah dilakukan tindakan pada pembelajaran berbasis $4 \mathrm{~K}$ pada siklus II ini, mereka diminta mengejakan soal esai pemecahan masalah.

Berdasarkan hasil analisis data untuk penelitian siklus II diperoleh informasi bahwa untuk tahap memahami masalah diperoleh skor rata-rata 88, tahap membuat rencana diperoleh skor rata-rata 80, tahap melaksanankan rencana diperoleh skor rata-rata 76, dan untuk tahap memeriksa kembali diperoleh skor rata-rata 75. Skor rata-rata kemampuan mahasiswa di kelas dalam memecahkan masalah diketahui meningkat dari 22.5 pada studi pendahuluan menjadi 60 pada siklus I dan 79.75 pada siklus II. Dengan demikian terjadi peningkatan kemampuan mahasiswa dalam memecahkan masalah dan semua mahasiswa sudah dapat memecahkan masalah hingga tahap melaksanakan rencana sesuai tahapan Polya. Sehingga penelitian ini sudah mencapai kriteria keberhasilan dalam meningkatkan kemampuan pemecahan masalah mahasiswa.

Berikut disajikan Tabel 2. peningkatan kemampuan pemecahan masalah mahasiswa dari studi pendahuluan hingga siklus II.

Tabel 2. Kemampuan Pemecahan Masalah Mahasiswa

\begin{tabular}{lccc}
\hline \multicolumn{1}{c}{ Tahapan Pemecahan } & \multicolumn{3}{c}{ Skor Rata-rata Mahasiswa di Kelas dalam Memecahkan Masalah } \\
Masalah & Studi Pendahuluan & Siklus I & Siklus II \\
\hline Memahami masalah & 65 & 80 & 88 \\
Membuat rencana & 15 & 63 & 80 \\
Melaksanakan rencana & 10 & 52 & 76 \\
Memeriksa kembali & 0 & 45 & 75 \\
Skor Total Rata-rata & 22.5 & 60 & 79.75 \\
\hline
\end{tabular}


Berdasarkan hasil penelitian, diketahui bahwa pembelajaran berbasis 4K yakni pembelajaran yang berbasis kritis, kreatif, komunikatif, dan kolaboratif dapat meningkatkan kemampuan pemecahan masalah mahasiswa. Pertama untuk aspek berpikir kritis, sesuai dengan pendapat Peter (2012) bahwa kemampuan berpikir kritis merupakan kemampuan yang dapat dipelajari dan dilatihkan yang dengan kemampuan ini seseorang akan mampu memecahkan masalah secara efektif. Kedua untuk aspek keatif, (Rahmazatullaili, Zubainur \& Munzir, 2017) menyatakan bahwa kemampuan berpikir kreatif memberikan pengaruh positif terhadap kemampuan pemecahan masalah. Selain itu, Yarmayani (2016) juga menyatakan bahwa berpikir kreatif dapat diwujudkan dengan menciptakan ide baru, memperluas ide atau konsep dasar untuk meningkatkan dan memaksimalkan upaya kreatif, dan mengaplikasikan ide kreatif sebagai kontribusi nyata yang sangat dibutuhkan dalam memecahkan masalah. Ketiga untuk aspek komunikatif, komunikasi digunakan untuk menyatakan gagasan matematis secara lisan, tulisan, serta menggambarkan secara visual, menginterpretasikan dan mengevaluasi gagasan-gagasan matematika secara lisan maupun tertulis, dan menggunakan istilah-istilah, simbol-simbol, dan struktur-struktur untuk memodelkan situasi atau permasalahan matematika (NCTM, 2000). Keempat untuk aspek kolaboratif, seperti yang diungkapkan (Laal \& Ghodsi, 2012) bahwa pembelajaran kolaboratif memperoleh hasil belajar lebih bagus daripada belajar secara individu dan juga (Mirza, Munawar \& Iqbal, 2014) mengatakan bahwa pembelajaran dengan kolaboratif efektif meningkatkan pemahaman konsep bagi pembelajar.

Pada siklus II dilakukan pembelajaran berbasis $4 \mathrm{~K}$ dengan tambahan tindakan khusus untuk aspek komunikasi yaitu setiap mahasiswa didorong untuk meningkatkan kemampuan komunikasinya dengan menjelaskan proses pemecahan masalah di hadapan semua temannya dengan kata lain mereka harus menunjukkan kemampuan atau performanya di depan publik. Hal ini sesuai dengan pendapat Mahajan (2014) bahwa untuk berpartisipasi penuh menunjukkan performa yang baik dalam publik diperlukan pemahaman matematika yang baik. Sehingga tindakan ini dapat lebih meningkatkan kemampuan pemecahan masalah mahasiswa.

\section{KESIMPULAN}

Berdasarkan hasil penelitian yang telah dilakukan menunjukkan bahwa pembelajaran matematika berbasis $4 \mathrm{~K}$ mampu meningkatkan kemampuan mahasiswa dalam memecahkan masalah. Pembelajaran 4K yang dilakukan pada penelitian ini yaitu mahasiswa diberikan 
permasalahan yang mendorong untuk berpikir kritis dan kreatif; mereka diminta untuk berkolaborasi dan saling berkomunikasi dalam kelompok; demonstrasi yang menuntut setiap mahasiswa berkomunikais di hadapan teman sekelas; dan mereka diminta untuk membuat atau mengajukan permasalahan untuk mendorong berpikir kreatif.

Penelitian selanjutnya dapat dilakukan untuk menggali lebih dalam bagaimana deskripsi masing-masing komponen $4 \mathrm{~K}$ berdasarkan indikator-indikator yang sudah disampaikan sebelumnya. Selain itu, penelitian pengembangan juga dapat dilakukan untuk mendukung penerapan pembelajaran berbasis $4 \mathrm{~K}$, misalnya pengembangan media pembelajaran.

\section{REKOMENDASI}

Berdasarkan hasil penelitian, rekomendasi yang dapat diberikan yaitu sebaiknya pada pembelajaran mata kuliah apapun, mahasiswa dibiasakan untuk menghadapi permasalahan yang mndorong untuk berpikir kritis dan kreatif; dan sebaiknya pengajar memberikan kesempatan seluas-luasnya kepada setiap pembelajar untuk mengungkapkan atau mengomunikasikan hasil kerjanya di hadapan semua teman di kelas.

\section{UCAPAN TERIMA KASIH}

Ucapan terima kasih penulis sampaikan kepada Kementrian Riset, Teknologi dan Pendidikan Tinggi yang telah mendukung penelitian kami dalam skema Penelitian Dosen Pemula tahun 2019 berdasarkan Surat Keputusan nomor 7/E/KPT/2019 .

\section{REFERENSI}

Ersoy, E. (2016). Problem Solving and Its Teaching in Mathematics. The Online Journal of New Horizons in Education, 6(2), 79-87.

Eviyanti, C.Y.; Surya, E.; Syahputra, E.; Simbolon, M. (2017). Improving the Students' Mathematical Problem Solving Ability by Applying Problem Based Learning Model in VII Grade at SMPN 1 Banda Aceh Indonesia. International Journal of Novel Research in Education and Learning, 4(2), 138-144.

Laal, M., \& Ghodsi, S. M. (2012). Benefits of collaborative learning. In Procedia - Social and Behavioral Sciences. https://doi.org/10.1016/j.sbspro.2011.12.091 
Mahajan, S. (2014). Mathematics for the 21st Century: What Should Students Learn?. Boston: Center for Curriculum Redesign.

Maharani, H. R. (2014). Creative Thinking in Mathematics: Are We Able To Solve Mathematical Problems in a Variety of Way? International Conference on Mathematics, Science, and Education.

Mahmudi, A. (2009). Komunikasi dalam Pembelajaran Matematika. Jurnal Mipmipa Unhalu, $8(1)$.

Masrurotullaily, Hobri, \& Suharto. (2013). Analisis Kemampuan Pemecahan Masalah Matematika Keuangan Berdasarkan Model Polya Siswa Smk Negeri 6 Jember. Penerapan Model Pembelajaran Quantum Teaching, Kadikma. https://doi.org/10.1038/nsmb.1427

Mirza, Munawar S. \& Iqbal, M. Z. (2014). Impact of Collaborative Teaching (CT) on Mathematics Students' Achievement in Pakistan. Journal of Research and Reflections in Education, 8(1), 13-21.

National Council Of Teachers Of Mathematics. (2000). Principles and Standards for School Mathematics. School Science and Mathematics. https://doi.org/10.1111/j.19498594.2001.tb17957.x

Ninik, Hobri, S. (2014). Analisis Kemampuan Pemecahan Masalah untuk Setiap Tahap Model Polya dari Siswa SMK Ibu Pakusari Jurusan Multimedia pada Pokok Bahasan Program Linier. Kadikma, 5(3), 61-68.

Pehkonen, E., Naveri, L. \& Laine, A. (2013). On Teaching Problem Solving in School Mathematics. Center for Educational Policy Studies Journal, 3(4), 9-23.

Peter, E. E. (2012). Critical thinking: Essence for teaching mathematics and mathematics problem solving skills. African Journal of Mathematics and Computer Science Research. https://doi.org/10.5897/AJMCSR11.161 
Rahmazatullaili, R., Zubainur, C. M., \& Munzir, S. (2017). Kemampuan berpikir kreatif dan pemecahan masalah siswa melalui penerapan model project based learning. Beta Jurnal Tadris Matematika. https://doi.org/10.20414/betajtm.v10i2.104

Shadiq, F. (2004). Pemecahan Masalah, Penalaran dan Komunikasi. Widyaiswara PPPG Matematika Yogyakarta.

Sulistyorini, Y., \& Napfiah, S. (2019). Analisis Kemampuan Berpikir Kritis Mahasiswa dalam Memecahkan Masalah Kalkulus. AKSIOMA, 8(2), 279-287.

Van Roekel, D. (2014). Preparing 21st Century Students for a Global Society: An Educator 's Guide to the "Four Cs." National Education Association.

Victor, T. (2015). The Challenges and Opportunities of Developing the 4C's in the Math Classroom. $\quad$ Retrieved March 4, 2019, from http://math.nie.edu.sg/ame/amesms15/download/K5.pdf

Yarmayani, A. (2016). Analisis Pemecahan Masalah Matematis Siswa Kelas XI MIPA SMA Negeri 1 Kota Jambi. Jurnal Ilmiah Dikdaya, 6(2), 12-19.

Yuniar, Siti Nastiti; Sunardi; Kurniawati, D. (2017). Pengembangan Indikator 4C's yang Selaras dengan Kurikulum 2013 SMA Kelas X Pada Materi Trigonometri. Kadikma, $8(3), 173-185$.

Zubaidah, S. (2010). Pembelajaran Kolaboratif dan Group Investigation (Sebagai Salah Satu Teknik Pembelajaran Kolaboratif). In Seminar Nasional Pembelajaran Biologi dengan Tema "Pengembangan Kemampuan Profesionalisme Guru melalui Pembelajaran Inovatif. Riau: Universitas Islam Riau. 